\title{
Killer Cell Immunoglobulin-Like Receptor 2DS1
}

National Cancer Institute

\section{Source}

National Cancer Institute. Killer Cell Immunog/obulin-Like Receptor 2DS1. NCI Thesaurus. Code C106094.

Killer cell immunog lobulin-like receptor 2DS1 (304 aa, $~ 34 \mathrm{kDa}$ ) is encoded by the human KIR2DS1 gene. This protein plays a role in natural killer cell-mediated immunity. 